\title{
PERANCANGAN DAN ANALISIS PEMBEBANAN GERGAJI RADIAL 4 ARAH
}

\author{
Michael Wijaya, Didi Widya Utama dan Agus Halim \\ Program Studi Teknik Mesin, Fakultas Teknik Universitas Tarumanagara, Jakarta \\ e-mail:mchwijaya@gmail.com
}

\begin{abstract}
: 4 ways hacksaw is one type of wood hacksaw, which has 4 arms wood hacksaw and connected by linkage, so that can make translation movement. This 4 ways hacksaw powered by 1,5 HP AC Motor. This 4 ways hacksaw design, performed modeling and construction load simulation was made and simulated by Autodesk Inventor Professional 2014 software. And also on this load simulation this product also had good strength and ability to receive the maximum load force. So it is safe to be use
\end{abstract}

Keywords: 4 ways hacksaw, construction design, construction load simulation

\begin{abstract}
Abstrak: Gergaji radial 4 arah adalah salah satu jenis gergaji kayu yang dimana memiliki 4 tangan pemotong gergaji yang dihubungkan dengan menggunakan link sehingga dapat melakukan gerakan trasnlasi. Gergaji radial 4 arah ini menggunakan tenaga dari AC motor dengan daya 1,5 HP. Gergaji radial 4 arah ini didesain dan dan dibentuk model serta konstruksi simulasi pembebanannya dibuat dengan menggunakan bantuan dari software Autodesk Inventor Professional 2014. Dan juga simulasi pembebanan dari produk ini memiliki kekuatan yang baik dan kemampuan yang baik untuk menerima beban gaya maksimum. Sehingga aman untuk digunakan.
\end{abstract}

Kata Kunci: gergaji radial 4 arah, disain konstruksi, simulasi beban konstruksi

\section{PENDAHULUAN}

Dalam kehidupan di dunia ini teknologi semakin canggih, dan setiap harinya juga semakin berkembang, dan menunjukkan kemajuan yang sangat pesat di bidang tersebut. Kemajuan yang yang paling pesat selain di bidang teknologi adalah bidang perindustrian. Industri furnitur merupakan salah satu industri yang memberikan pengaruh yang cukup besar dalam kemajuan bidang industri dewasa ini, banyak pabrik pabrik yang bergerak dibidang ini.

Salah satu proses pengolahan kayu adalah dengan memotong kayu tersebut menjadi bagian yang lebih kecil, alat yang biasa digunakan untuk memotong kayu adalah gergaji. Gergaji merupakan salah satu alat yang digunkaan untuk memotong kayu. Ada berbagai jenis gergaji, seperti gergaji mesin dan gergaji tangan. Namun untuk industri kecil biasanya anya menggunakan gergaji tangan, dan ini akan memakan waktu dan juga tenaga, karena harus dilakukan satu persatu dalam melakukan pemotongan kayu dengan gergaji tersebut.

Maka sangat diperlukan alat yang bisa melakukan kegiatan memotong kayu tersebut untuk perindustrian kecil yang lebih cepat dan juga memiliki harga yang lebih terjangkau, serta tidak memakan tenaga banyak, sehingga pekerja dapat melakukan pekerjaan lain yang dapat lebih meningkatkan kegiatan produksi dan estimasi waktu yang ditetapkan.

\section{METODE PENELITIAN}

Metode penelitian yang digunakan dalam perancangan konstruksi pada gergaji radial 4 arah ini adalah analitis untuk menganalisis kekuatan rangka, desain, dan sistem transmisi, dengan menggunakan software dan metode perancangan VDI 2221 untuk melakukan pemecahan masalah dan analisis masalah yang dilakukan secara bertahap.

Penelitian di awali dengan mengumpulkan informasi yang dibutuhkan untuk perancangan dari gergaji radial 4 arah ini. Informasi dikumpulkan melalui berbagai cara, seperti internet, pustaka, dan penelitian lapangan. Kemudian dilakukan peroses perhitungan dan pemodelan 3 dimensi desain gergaji radial 4 arah untuk kemudian dianalisis kekuatan konstruksinya. Menggunakan software. Apabila rancangan tidak terjadi tegangan yang melebihi tegangan ijin material, maka rancangan dianggap aman dan juga apabila sistem transmisi dapat berjalan dengan lancar, maka rancangan dianggap aman, dan dapat dilakukan dengan pembuatan komponen. 
Komponen yang sudah dibuat kemudian dirakit dan kemudian dilakukan pengujian langsung dilihat dari sisi sistem transmisi dan kekuatan rangka terhadap pembebanan. Apabila sistem transmisi dan kekuatan rangka berjalan dengan lancar dan kuat, maka perancangan dikatakan sesuai dengan analisis kekuatan dan perhitungan sistem transmisi.

Pemodelan dalam bentuk 3 dimensi dan analisis kekuatan konstruksi mengggunakan software Autodesk Inventor Professional 2014. Analisis kekuatan konstruksi dilakukan dengan mempelajari tegangan, regangan, dan pergeseran yang terjadi apda komponen yang dirancang. Kemudian analisis sistem transmisi yang digunakan dilakukan dengan memepelajari kekuatan daya, sitem transmisi, dan kinematika dan dinamika.

Komponen yang dibutuhkan pada perancangan gergaji radial 4 arah ini meliputi, besi hollow, besi siku, engsel, plat, motor AC, gearbox, gergaji, besi siku, dan kayu.

\begin{tabular}{|c|c|c|c|c|}
\hline No & Sub Fungsi & 1 & 2 & 3 \\
\hline 1 & Penggerak & $\begin{array}{l}\text { Motor Listrik } \\
\mathrm{AC}\end{array}$ & $\begin{array}{l}\text { Motor Listrik } \\
\text { DC }\end{array}$ & \\
\hline 2 & Penerus Daya & Sabuk \& & $\begin{array}{l}\text { Pantai c } \\
\text { Sproket }\end{array}$ & \\
\hline 3 & Mata Gergaji & Belah & totong & \\
\hline 4 & Reduksi Putaran Motor & Sproket & Wormgear & डेpur Gear \\
\hline 5 & Bentuk Material & Silinder Pejak & Angle Bar & Hollow Bar \\
\hline 6 & Material Rangka & Aluminiun & Besi & Baja \\
\hline 7 & $\begin{array}{l}\text { Arah Gerakan } \\
\text { Penggergajian }\end{array}$ & Satu Ara: & $\mathrm{Bol}$ & \\
\hline
\end{tabular}

Gambar 1. Diagam alir perancangan Gergaji Radial 4 Arah

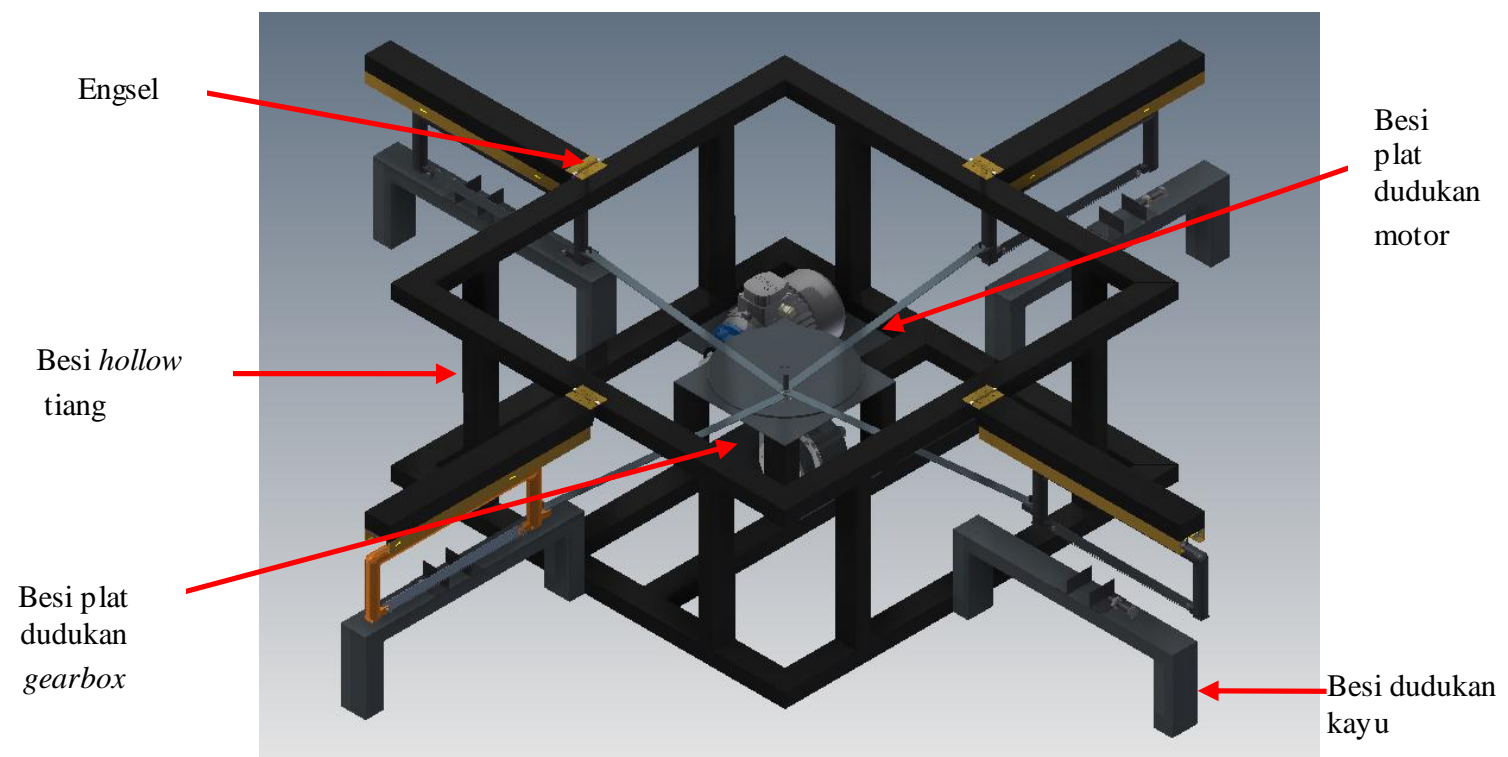

Gambar 2. Model Gergaji Radial 4 Arah 


\section{HASIL DAN PEMBAHASAN}

Simulasi pembebanan konstruksi Gergaji Radial 4 Arah dilakukan dengan memberikan pembebanan terhadap besi plat untuk dudukan motor AC, besi plat untuk dudukan gearbox, engsel pada track gergaji, dudukan kayu yang akan dipotong, link, piringan dan poros.

Simulasi pembebanan pada dudukan motor dilakukan dengan memberikan beban pada bagian yang menopang sebesar $150 \mathrm{~N}$, dimana beban tersebut merupakan beban dari motor AC 1,5 HP, dengan percepatan gravitasi $9,81 \mathrm{~m} / \mathrm{s}^{2}$. Material yang digunakan adalah Carbon Steel AISI 1020 plat dengan ukuran panjang $335 \mathrm{~mm}$, lebar $300 \mathrm{~mm}$ dan tebal $5 \mathrm{~mm}$. Kemudian untuk penentuan harga safety factor yaitu dengan menggunakan metode Thumb.

\section{$\mathrm{SF}=\mathrm{SF}$ material $\mathrm{x}$ SF tegangan $\mathrm{x}$ SF geometri $\mathrm{x}$ SF analisis kegagalan $\mathrm{x}$ SF keandalan}

$\mathrm{SF}=1,1 \times 1,0 \times 1,0 \times 1,5 \times 1,6=2,64$ dibulatkan menjadi 3. Yield strength untuk material Carbon Steel AISI 1020 sebesar $207 \mathrm{MPa}$, dan telah ditentukan harga safety factor adalah 3. Tegangan ijin yang didapat adalah sebesar $69 \mathrm{MPa}$, kemudian hasil dari von mises stress adalah sebesar 3,45 MPa. Sehingga dapat dikatan aman karena von mises stress yang terjadi lebih kecil dibandingkan dengan tegangan ijin dari material. Kemudian untuk defleksi yang terjadi adalah sebesar 0,02 mm.
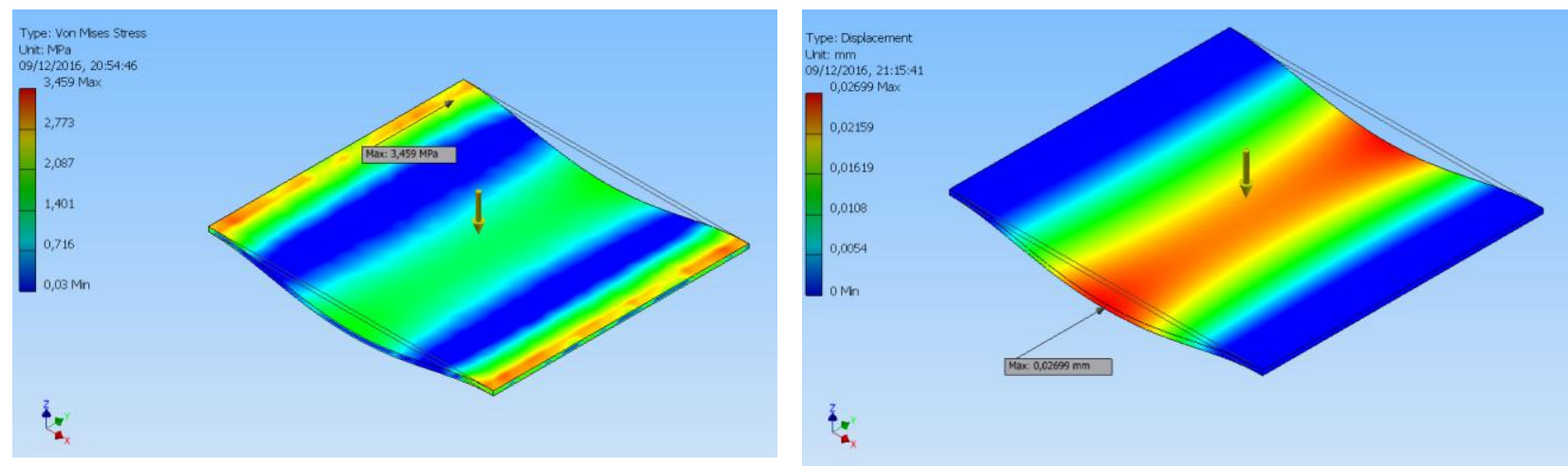

Gambar 3. (a) Von mises stress besi plat dudukan motor (b) Displacement besi plat dudukan motor

Simulasi pembebanan pada dudukan worm gearbox dilakukan dengan memberikan beban pada bagian yang menopang sebesar $150 \mathrm{~N}$, dimana beban tersebut merupakan beban dari worm gearbox, sprocket, washer, dan poros dan piringan roda daya, dengan percepatan gravitasi $9,81 \mathrm{~m} / \mathrm{s}^{2}$. Material yang digunakan adalah Carbon Steel AISI 1020 plat dengan ukuran panjang $310 \mathrm{~mm}$, lebar $230 \mathrm{~mm}$ dan tebal $3 \mathrm{~mm}$. Kemudian untuk penentuan harga safety factor yaitu dengan menggunakan metode Thumb.

\section{$\mathrm{SF}=\mathrm{SF}$ material $\times \mathrm{SF}$ tegangan $\times \mathrm{SF}$ geometri $\times \mathrm{SF}$ analisis kegagalan $\times \mathrm{SF}$ keandalan}

$\mathrm{SF}=1,1 \times 1,0 \times 1,0 \times 1,5 \times 1,6=2,64$ dibulatkan menjadi 3. Yield strength untuk material Carbon Steel AISI 1020 sebesar $207 \mathrm{MPa}$, dan telah ditentukan harga safety factor adalah 3. Tegangan ijin yang didapat adalah sebesar $69 \mathrm{MPa}$, kemudian hasil dari von mises stress adalah sebesar 10,45 MPa. Sehingga dapat dikatan aman karena von mises stress yang terjadi lebih kecil dibandingkan dengan tegangan ijin dari material. Kemudian untuk defleksi yang terjadi adalah sebesar $0,11 \mathrm{~mm}$. 


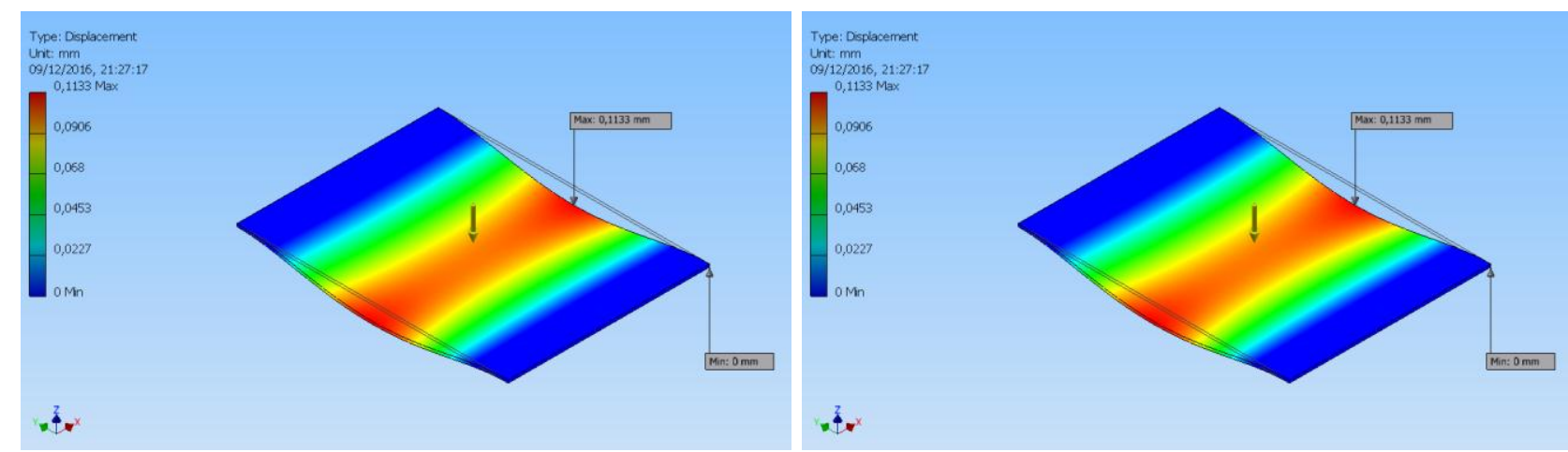

Gambar 4. (a) Von mises stress besi plat dudukan worm gearbox (b) Displacement besi plat dudukan worm gearbox

Simulasi pembebanan pada engsel dilakukan dengan memberikan momen sebesar $20000 \mathrm{Nmm}$, di mana momen tersebut merupakan hasil dari perhitungan antara gaya yang terjadi di gergaji dikali dengan panjang lengan gergaji tersebut, dengan percepatan gravitasi $9,81 \mathrm{~m} / \mathrm{s}^{2}$. Material yang digunakan adalah stainless steel 304 (engsel pintu). Kemudian untuk penentuan harga safety factor yaitu dengan menggunakan metode Thumb.

\section{$\mathrm{SF}=\mathrm{SF}$ material $\times \mathrm{SF}$ tegangan $\mathrm{x}$ SF geometri $\mathrm{x}$ SF analisis kegagalan $\times \mathrm{SF}$ keandalan}

$\mathrm{SF}=1,0 \times 1,0 \times 1,0 \times 1,0 \times 1,2=1,2$. Yield strength untuk material stainless steel 304 sebesar $241 \mathrm{MPa}$, dan telah ditentukan harga safety factor adalah 1,2. Tegangan ijin yang didapat adalah sebesar $200 \mathrm{MPa}$, kemudian hasil dari von mises stress adalah sebesar 196,745 MPa. Sehingga dapat dikatan aman karena von mises stress yang terjadi lebih kecil dibandingkan dengan tegangan ijin dari material. Kemudian untuk defleksi yang terjadi adalah sebesar 0,013 mm.
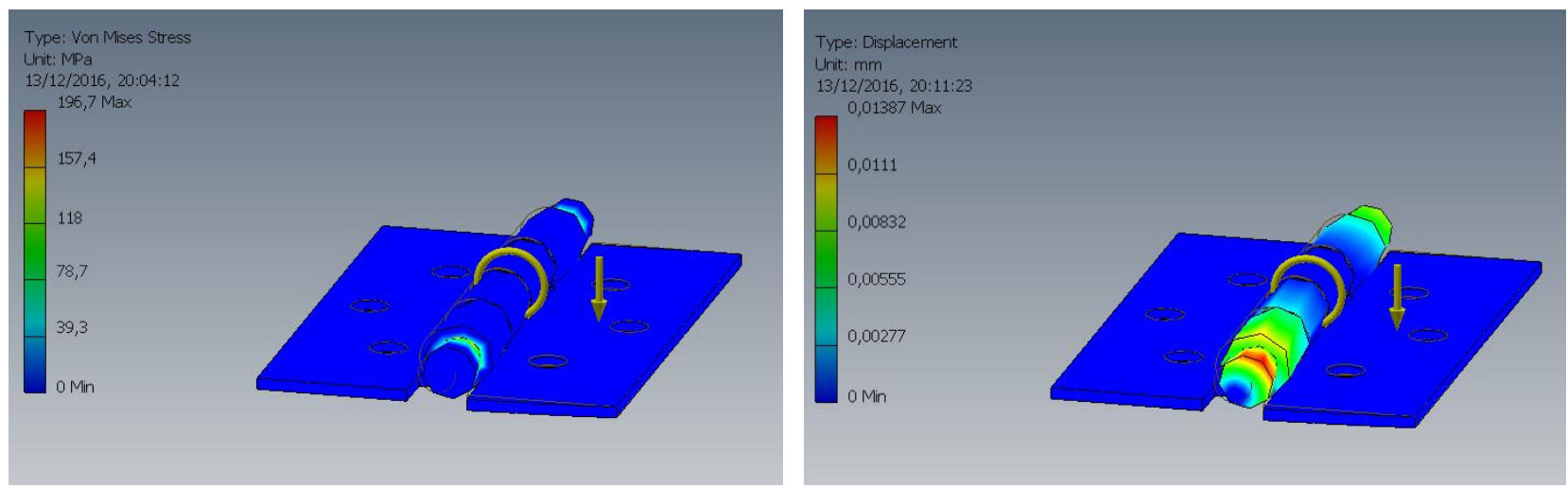

Gambar 5. (a) Von mises stress engsel (b) Displacement engsel

Simulasi pembebanan pada dudukan kayu dilakukan dengan memberikan beban sebesar $70 \mathrm{~N}$, di mana beban tersebut merupakan beban dari gergaji dan kayu yang akan dipotong, dengan percepatan gravitasi $9,81 \mathrm{~m} / \mathrm{s}^{2}$. Material yang digunakan adalah Carbon Steel AISI 1020. Kemudian untuk penentuan harga safety factor yaitu dengan menggunakan metode Thumb.

$\mathrm{SF}=\mathrm{SF}$ material $\times \mathrm{SF}$ tegangan $\times \mathrm{SF}$ geometri $\times \mathrm{SF}$ analisis kegagalan $\times \mathrm{SF}$ keandalan

$\mathrm{SF}=1,1 \times 1,0 \times 1,0 \times 1,5 \times 1,6=2,64$ dibulatkan menjadi 3. Yield strength untuk material Carbon Steel AISI 1020 sebesar $207 \mathrm{MPa}$, dan telah ditentukan harga safety factor adalah 3. Tegangan ijin yang didapat adalah sebesar $69 \mathrm{MPa}$, kemudian hasil dari von mises stress adalah sebesar 0,5 MPa. 
Sehingga dapat dikatan aman karena von mises stress yang terjadi lebih kecil dibandingkan dengan tegangan ijin dari material. Kemudian untuk defleksi yang terjadi adalah sebesar 0,11 mm.

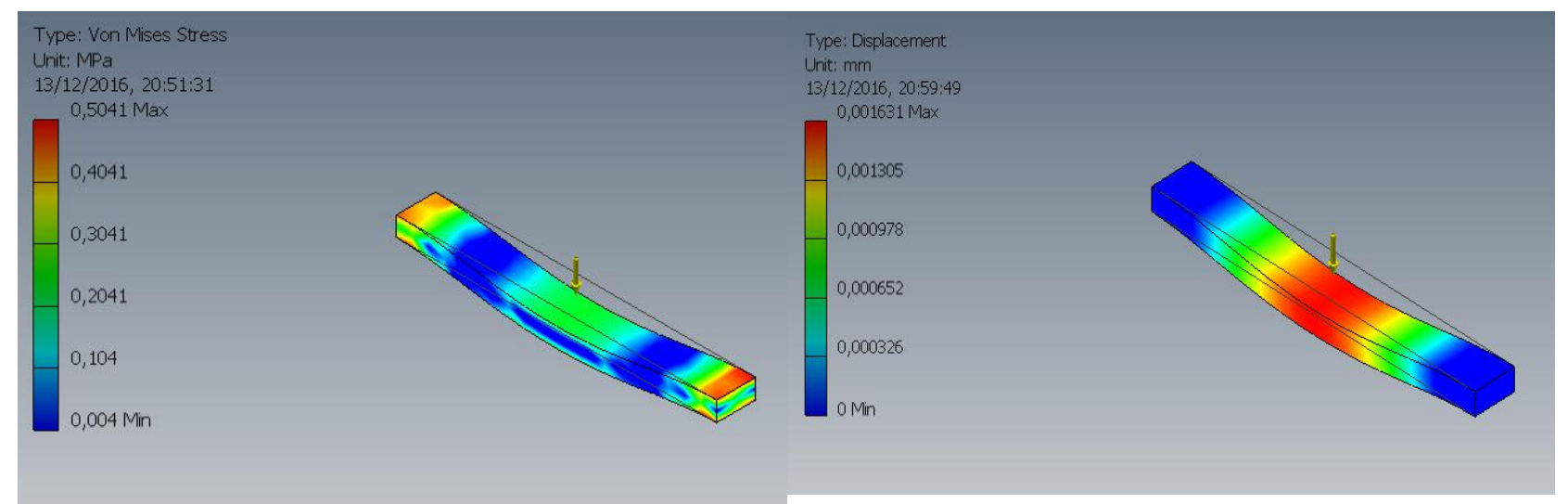

Gambar 6. (a) Von mises stress besi dudukan kayu (b) Displacement besi dudukan kayu

Simulasi pembebanan pada flywheel dan poros dilakukan dengan memberikan beban momen sebesar $11600 \mathrm{Nmm}$, di mana momen tersebut merupakan hasil perhitungan sistemasi link, dengan gaya $232 \mathrm{~N}$ dan panjang poros $50 \mathrm{~mm}$, dengan percepatan gravitasi $9,81 \mathrm{~m} / \mathrm{s}^{2}$. Material yang digunakan adalah Carbon Steel AISI 1020. Kemudian untuk penentuan harga safety factor yaitu dengan menggunakan metode Thumb.

$\mathrm{SF}=\mathrm{SF}$ material $\times \mathrm{SF}$ tegangan $\times \mathrm{SF}$ geometri $\times \mathrm{SF}$ analisis kegagalan $\times \mathrm{SF}$ keandalan

$\mathrm{SF}=1,1 \times 1,0 \times 1,0 \times 1,5 \times 1,6=2,64$ dibulatkan menjadi 3. Yield strength untuk material baja karbon SC45 sebesar $328 \mathrm{MPa}$, dan telah ditentukan harga safety factor adalah 3. Tegangan ijin yang didapat adalah sebesar $114 \mathrm{MPa}$, kemudian hasil dari von mises stress adalah sebesar 2,95 MPa. Sehingga dapat dikatan aman karena von mises stress yang terjadi lebih kecil dibandingkan dengan tegangan ijin dari material. Kemudian untuk defleksi yang terjadi adalah sebesar 0,001 mm.
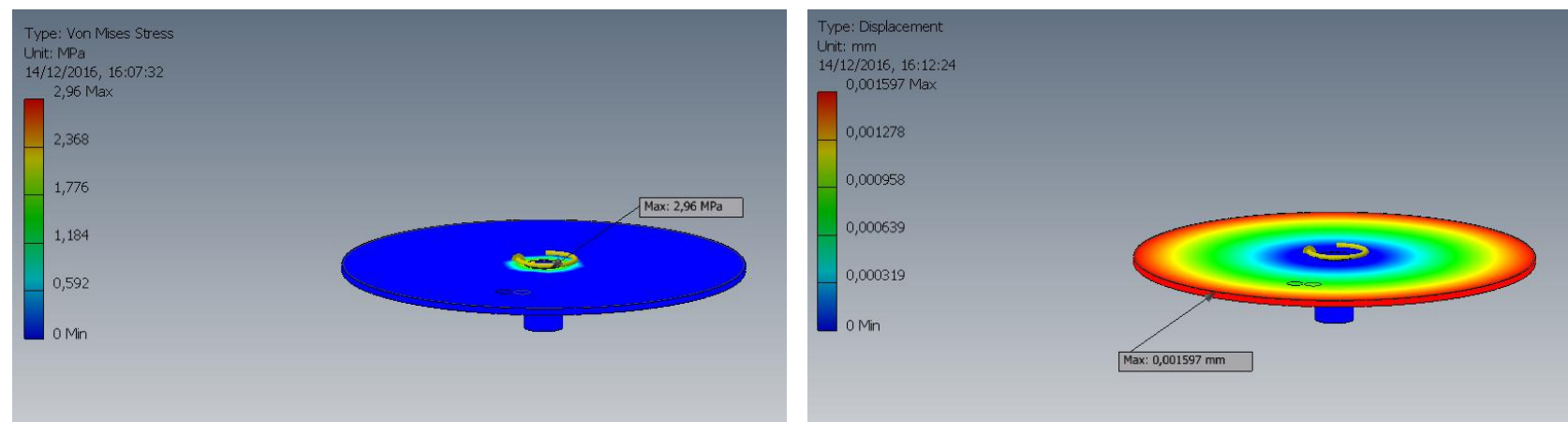

Gambar 7. (a) Von mises stress flywheel dan poros (b) Displacement flywheel dan poros

Simulasi pembebanan pada link dilakukan dengan memberikan momen sebesar $17400 \mathrm{Nmm}$, di mana momen tersebut merupakan hasil dari perhitungan sistem kerja link, dengan percepatan gravitasi $9,81 \mathrm{~m} / \mathrm{s}^{2}$. Material yang digunakan adalah Carbon Steel AISI 1020 plat dengan ukuran panjang $600 \mathrm{~mm}$, dan tebal $3 \mathrm{~mm}$. Kemudian untuk penentuan harga safety factor yaitu dengan menggunakan metode Thumb.

$\mathrm{SF}=\mathrm{SF}$ material $\mathrm{x}$ SF tegangan $\mathrm{x}$ SF geometri $\mathrm{x}$ SF analisis kegagalan $\mathrm{x}$ SF keandalan 
$\mathrm{SF}=1,0 \times 1,0 \times 1,0 \times 1,1 \times 1,6=1,92$ dibulatkan menjadi 2. Yield strength untuk material Carbon Steel AISI 1020 sebesar $207 \mathrm{MPa}$, dan telah ditentukan harga safety factor adalah 2. Tegangan ijin yang didapat adalah sebesar 103,5 $\mathrm{MPa}$, kemudian hasil dari von mises stress adalah sebesar 88,2925 MPa. Sehingga dapat dikatan aman karena von mises stress yang terjadi lebih kecil dibandingkan dengan tegangan ijin dari material. Kemudian untuk defleksi yang terjadi adalah sebesar $0,92 \mathrm{~mm}$.

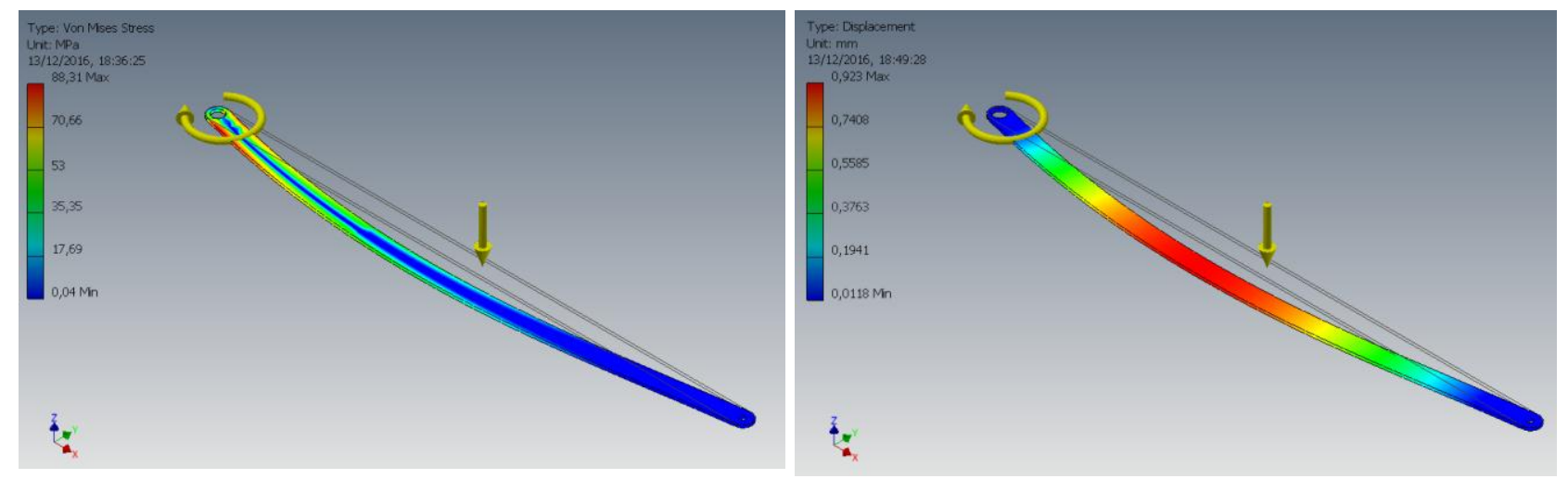

Gambar 8. (a) Von mises stress link (b) Displacement link

Tabel 1. Hasil perhitungan analisis link gergaji radial 4 arah

\begin{tabular}{ccc}
\hline No. & Komponen & Nilai \\
\hline 1 & $\omega_{2}$ & $7,854 \mathrm{rad} / \mathrm{s}$ \\
2 & $\mathrm{~V}_{\mathrm{b}}$ & $0,7854 \mathrm{~m} / \mathrm{s}$ \\
3 & $\mathrm{~V}_{\mathrm{c} / \mathrm{b}}$ & $0,46 \mathrm{~m} / \mathrm{s}$ \\
4 & $\omega_{3}{ }{ }$ & $0,6 \mathrm{rad} / \mathrm{s}$ \\
5 & $\mathrm{~A}_{\mathrm{b}}=\mathrm{A}_{\mathrm{b}}{ }^{2}$ & $6.168 \mathrm{~m} / \mathrm{s}^{2}$ \\
6 & $\mathrm{~A}_{\mathrm{c} / \mathrm{b}}{ }^{\mathrm{t}}$ & $0,352 \mathrm{~m} / \mathrm{s}^{2}$ \\
7 & $\mathrm{~A}_{\mathrm{c} / \mathrm{b}}$ & $5,2 \mathrm{~m} / \mathrm{s}^{2}$ \\
8 & $\mathrm{~A}_{\mathrm{c} / \mathrm{b}}$ & $5,1 \mathrm{~m} / \mathrm{s}^{2}$ \\
9 & $\mathrm{~A}_{\mathrm{c}}$ & $3,5 \mathrm{~m} / \mathrm{s}^{2}$ \\
10 & $\alpha_{3}$ & $8,67 \mathrm{rad} / \mathrm{s}^{2}$ \\
11 & $\mathrm{AG}_{3}$ & $4,2 \mathrm{~m} / \mathrm{s}^{2}$ \\
12 & $\mathrm{f}_{3}$ & $4,2 \mathrm{~N}$ \\
13 & $\mathrm{f}_{4}$ & $4,55 \mathrm{~N}$ \\
14 & $\mathrm{I}_{3}$ & $0,021 \mathrm{kgm}$ \\
15 & $\mathrm{~h}_{3}$ & $43,35 \mathrm{~mm}$ \\
16 & $\mathrm{~F}_{14}$ & $32,47 \mathrm{~N}$ \\
17 & $\mathrm{~F}_{23}=\mathrm{F}_{32}=\mathrm{F}_{12}=\mathrm{F}_{21}$ & $232 \mathrm{~N}$ \\
18 & $\mathrm{~h}_{2}$ & $75 \mathrm{~mm}$ \\
19 & $\mathrm{~T}_{2}$ & $17,4 \mathrm{Nm}$ \\
20 & $\mathrm{~T}_{\text {total }}$ & $69,6 \mathrm{~N}$ \\
21 & $\mathrm{Fs}$ & $13,4 \mathrm{~N}$ \\
22 & $\mathrm{P}$ & $655,964 \mathrm{watt}$ \\
23 & $\mathrm{P}_{\text {rencana }}$ & $983,9 \mathrm{watt}$ \\
24 & $\mathrm{Lp}_{2}$ & $815 \mathrm{~mm}$ \\
25 & $\mathrm{D}_{\mathrm{p}}$ & $20,6 \mathrm{~mm}$ \\
\hline
\end{tabular}

Hasil simulasi pembebanan yang dilakukan menggunakan bantuan dari Autodesk Inventor 2014, menunjukan bahwa beban yang diberikan keapada Gergaji Radial 4 Arah ini dapat ditopang dengan baik dan tidak mengalami kerusakan akibat beban yang diberikan dan gaya yang bekerja. Hasil simulasi pembebanan setiap komponen dapat dilihat pada Tabel 2. 
Tabel 2. Hasil Simulasi Pembebanan pada Komponen Gergaji Radial 4 Arah

\begin{tabular}{|c|c|c|c|c|c|c|c|c|}
\hline No. & Komponen & Material & $\begin{array}{c}\sigma_{\mathrm{y}} \\
(\mathrm{Mpa})\end{array}$ & $\mathrm{SF}$ & $\begin{array}{c}\sigma_{\mathrm{ijin}} \\
(\mathrm{Mpa})\end{array}$ & $\begin{array}{c}\sigma_{\text {maks }} \\
(\mathrm{Mpa})\end{array}$ & $\begin{array}{c}\text { Defleksi } \\
\text { Maksimum }\end{array}$ & Ket. \\
\hline 1 & $\begin{array}{l}\text { Dudukan } \\
\text { Motor }\end{array}$ & $\begin{array}{l}\text { Carbon Steel AISI } \\
1020\end{array}$ & 207 & 3 & 69 & 3,45 & 0,02 & Aman \\
\hline 2 & $\begin{array}{l}\text { Dudukan } \\
\text { Worm Gearbox }\end{array}$ & $\begin{array}{l}\text { Carbon Steel AISI } \\
1020\end{array}$ & 207 & 3 & 69 & 10,45 & 0,11 & Aman \\
\hline 3 & Link & $\begin{array}{l}\text { Carbon Steel AISI } \\
1020\end{array}$ & 207 & 2 & 103,5 & 88,29 & 0,92 & Aman \\
\hline 4 & Engsel & Stainless Steel 304 & 241 & 1,2 & 200 & 196,74 & 0,013 & Aman \\
\hline 5 & Dudukan Kayu & $\begin{array}{l}\text { Carbon Steel AISI } \\
1020\end{array}$ & 207 & 3 & 69 & 0,5 & 0,11 & Aman \\
\hline 6 & $\begin{array}{l}\text { Flywheel dan } \\
\text { poros }\end{array}$ & Carbon Steel S45C & 328 & 3 & 109 & 2,95 & 0,001 & Aman \\
\hline
\end{tabular}

\section{KESIMPULAN}

Setelah melakukan perancangan Gergaji Radial 4 Arah dengan penggerak motor listrik, terdapat beberapa hal yang dapat disimpulkan, yaitu :

1. Gergaji Radial 4 arah dapat memotong kayu dengan keteguhan belah maksimal $364 \mathrm{~kg} / \mathrm{mm}$.

2. Gergaji Radial 4 Arah ini memiliki dimensi p x 1 x t yaitu $2300 \mathrm{~mm}$ x $2300 \mathrm{~mm}$ x $480 \mathrm{~mm}$ dengan berat total $90 \mathrm{~kg}$

3. Material yang digunakan pada rangka dasar adalah hollow steel (AISI 1020), material untuk link, dudukan worm gearbox, dan dudukan motor adalah baja plat (AISI 1020), material untuk engsel adalah stainless steel 304.

4. Hasil simulasi setiap part Gergaji Radial 4 Arah yang mengalami pembebanan dan momen menggunakan fitur stress analysis pada software Autodesk Inventor menunjukkan bahwa rancangan konstruksi Gergaji Radial 4 Arah tergolong aman karena seluruh tegangan maksimum yang terjadi pada komponen gergaji tidak melibihi tegangan ijin material.

\section{DAFTAR PUSTAKA}

[1]. A.P. Irawan, "Diktat Elemen Mesin," p. 129, 2009

[2]. M. D. Kraige, ENGINEERING MECHANICS, STATICS, Volume 1, 2nd Edition, Jakarta: Erlangga, 1987

[3]. R. J. G. Khurmi, A Textbook of Machine Design., New Delhi: S.I. Units. Eurasia Publishing House (Pvt) Ltd., 2004

[4]. S. D. K. Suga, Dasar Perencanaan Dan Pemilihan Elemen Mesin, Jakarta: Pradnya Paramita, 1983. 